\title{
Analysis on the Innovative Quality Structure and Innovative Education of art Design Talents
}

\author{
Zhang Rui \\ Nanyang Institute of Technology, Nanyang Henan, 473004, China \\ Master of Art and Design \\ Henan University, Lecturer, Nanyang Institute of Technology, Art and Design \\ skycoco616@163.com
}

Keywords: Artistic design talents; Quality structure; Innovative education

\begin{abstract}
With the development of economy and society, art design has been extended to various fields of human production and social life. Especially in the fierce international market competition, innovation design has become an important factor to determine the market competitiveness under the circumstance that the products have no obvious difference in their use function and manufacturing quality. The cultivation of creative quality of students in art colleges and universities has become the primary task of training artistic design talents. This paper analyzes the creative ability and personality characteristics of art design talents, as well as the specific composition of creative qualities. It is emphasized that creative quality education is an important aspect of the overall quality training of art and design talents.
\end{abstract}

\section{Introduction}

Art design is a multidisciplinary and practical comprehensive subject. It is a science of creating material and spiritual products of human life according to the principle of combining art with science and technology. The education of art design serves for the cultivation of talents of art design, so the essence of art education is to train the mixed-mode, high-quality and innovative artistic design talents of the combination of art and science and technology [1-4]. The cultivation of art and design talents has obvious characteristics of the times, and the rapid development of the society has put forward new requirements for the cultivation of artistic design talents. Only when we have a deep understanding of this point can we grasp the direction of talent cultivation correctly. The emphasis of the new training mode of artistic design talents should be to cultivate the creative consciousness and ability of the talents, and to pay attention to the integration and systematization of knowledge in the training of knowledge so that the students can have more comprehensive professional knowledge structure and stronger professional research ability. Thus, they can become the composite talents needed by the society. It is necessary to pay attention to the cultivation of practical ability in the ability cultivation, making the student have strong comprehensive innovation ability. As shown in Table 1 and figure 1, according to statistics, 750 colleges and universities have set up "Art Design Specialty" in our country, and the enrollment scale is very large and is expanding constantly [5-7]. 
Table1 Summary of the number of institutions offering "art design specialty" in China

\begin{tabular}{|c|c|c|c|c|c|c|c|}
\hline $\begin{array}{c}\text { Provinc } \\
\mathrm{e}\end{array}$ & $\begin{array}{c}\text { Speciali } \\
\text { zed } \\
\text { institute } \\
\text { s }\end{array}$ & $\begin{array}{c}\text { Compre } \\
\text { hensive } \\
\text { institute } \\
\mathrm{s}\end{array}$ & Total & $\begin{array}{c}\text { Provinc } \\
\mathrm{e}\end{array}$ & $\begin{array}{c}\text { Speciali } \\
\text { zed } \\
\text { institute } \\
\text { s }\end{array}$ & $\begin{array}{c}\text { Compre } \\
\text { hensive } \\
\text { institute } \\
\mathrm{s}\end{array}$ & Total \\
\hline Beijing & 5 & 43 & 48 & Hubei & 1 & 51 & 52 \\
\hline Tianjin & 1 & 20 & 21 & Hunan & 0 & 27 & 27 \\
\hline Hebei & 1 & 30 & 31 & $\begin{array}{l}\text { Guangd } \\
\text { ong }\end{array}$ & 1 & 30 & 31 \\
\hline Shanxi & 0 & 13 & 13 & Guangxi & 1 & 21 & 22 \\
\hline $\begin{array}{c}\text { Nei } \\
\text { Monggo } \\
1\end{array}$ & 0 & 13 & 13 & Hainan & 0 & 5 & 5 \\
\hline $\begin{array}{c}\text { Liaonin } \\
\mathrm{g}\end{array}$ & 4 & 35 & 39 & $\begin{array}{c}\text { Chongqi } \\
\text { ng }\end{array}$ & 3 & 17 & 20 \\
\hline Jilin & 0 & 24 & 24 & Sichuan & 2 & 31 & 33 \\
\hline $\begin{array}{l}\text { Heilongj } \\
\text { iang }\end{array}$ & 0 & 20 & 20 & Guizhou & 0 & 14 & 14 \\
\hline
\end{tabular}

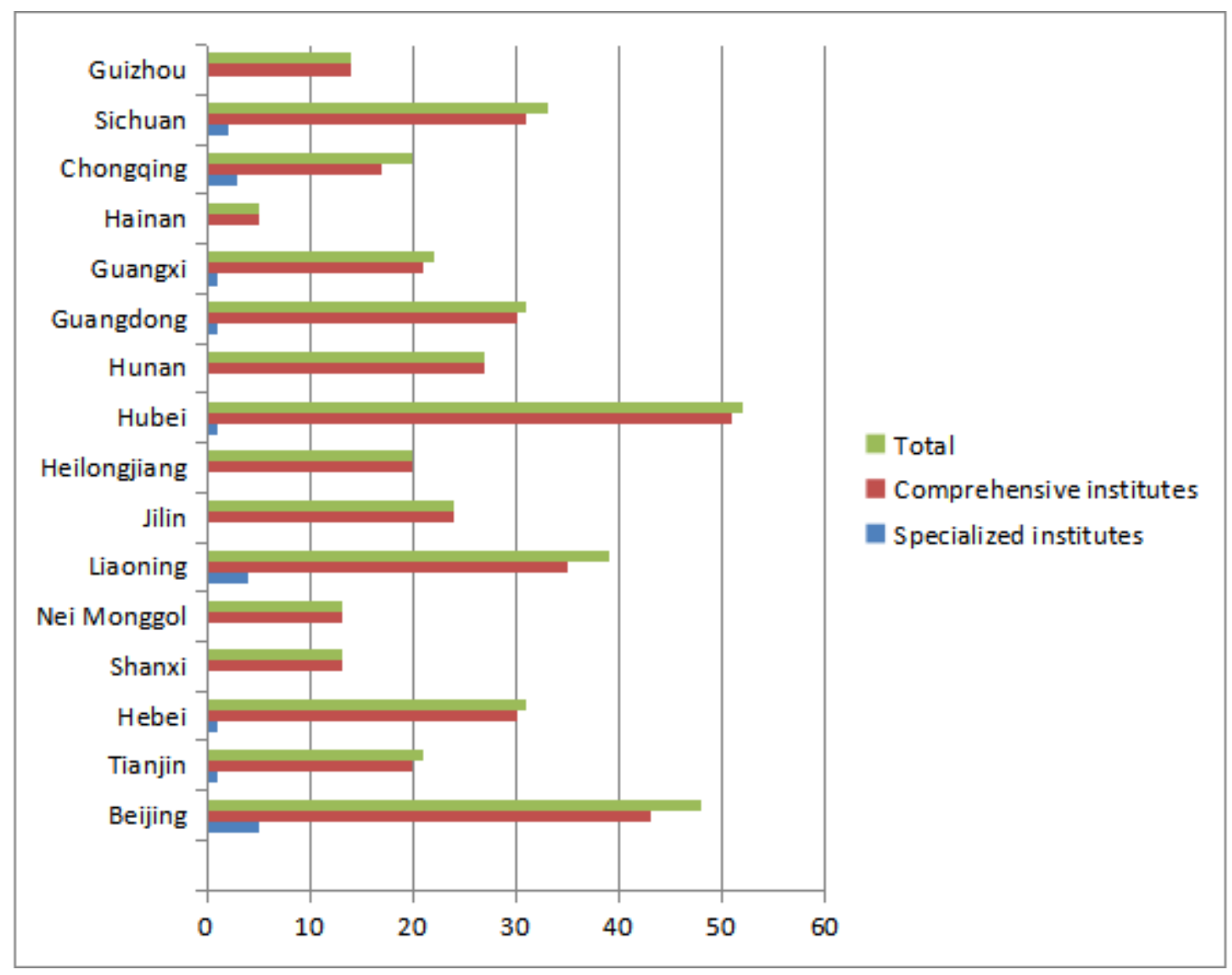

Figure 1 The number of colleges and universities opening the undergraduate course of "Art Design Specialty" 


\section{Research on the Structure of Creative Quality based on Art and Design Talents}

The quality composition of creative art design talents includes innovation consciousness, innovative spirit, innovation ability and innovative personality.

Innovation consciousness refers to being good at finding new problems, wanting to be outstanding in innovation and being able to consciously produce innovative motivation, which is the essential quality of innovative talents and the starting point of innovation. We should be good at making use of students' subjective initiative of innovation and promote and strengthen students' consciousness and insight of pursuing innovation through the application of various teaching links and teaching methods.

Innovative spirit mainly includes a high degree of professionalism, pioneering spirit, tough character and strong curiosity about new things. This is the basic quality of innovative talents, and also the source of power for innovation. Innovative talents generally have the characteristics of broad vision. Innovation is a new practical activity based on previous experience, knowledge and theory, including summing up the new experience, new knowledge, and new technology or producing new products.

Creative ability refers to creative thinking ability and creative ability to plan, organize and implement design activities, as well as the ability to creatively develop and design products, which is the core quality of innovative talents and the essential force of innovation.

Innovative personality is a kind of psychological behavior mode with individualized and relatively stable characteristics, which is the stable psychological characteristic of creative talents and the fundamental guarantee of continuous innovation. Innovative personality mainly refers to the sum of the characteristics of personality, temperament, and ability, which is embodied in innovation motivation, creative emotion, innovative will, innovative willpower and innovative behavior. This is not only influenced by heredity but also the education and cultivation.

\section{Research on the Innovative Education Method Based on Art Design Talents}

\section{Broaden the professional caliber and refine the professional content}

Desalination of professional boundaries and the implementation of professional cross and integration are needed. According to the requirements of the training goal, we comb the original specialty, broaden the professional caliber, refine the professional content, integrate and optimize the existing specialty, and enhance the adaptability of the specialty.

\section{Establish a distinctive curriculum system}

The compound knowledge structure is the requirement for talents in the new century, which should be paid attention to when making teaching plans. The teaching plan is the concrete embodiment of the idea of running a school and the goal of training, and it is also a platform for constructing the knowledge structure of talents. In the design of the teaching plan, the systematic and scientific knowledge system should be emphasized. According to the principles of broadening the foundation, integrating the courses, strengthening the systematicness and paying attention to the integration of the major, the teaching contents can be designed so that the teaching plan can meet the requirements of the talent training model and form a distinctive curriculum system with distinctive characteristics.

\section{Strengthen the study of practical courses and enhance students' practical ability}

The ultimate goal of design education is to give students the ability to solve practical problems. A number of laboratories have been set up in the school, in which computer practice and various professional skill practices are the main elements. By using the method of teaching in class and setting up experiment teaching in parallel, the practice teaching and classroom teaching are made two lines of teaching, and the two lines are combined with and verified each other so that the students can apply the theoretical knowledge they have learned to the design practice. At the same time, it is necessary to arrange the practice teaching in a concentrated way and use the market practice course of "one-stop" of professional investigation and internship to realize the alternating infiltration of the theory teaching and the practice teaching, so as to make the students close to the 
specialty, the market and the society, thereby enhancing their actual practical ability.

\section{Emphasize openness and practicality in the content of the course}

Course teaching is the core of the talent training mode, and the teaching material is the basis of realizing curriculum contents. In the teaching goal of the course, the lower grade curriculum is mainly to develop thinking, and the teaching content is open and active with a big jump degree; the emphasis is to let the students learn the design thinking method and the innovative knowledge and ability. The senior curriculum combines the scientific nature of the subject with the market practicability and emphasizes the combination of theory and practice. In the teaching content, we should establish the design teaching module focusing on the subject, and set up small and many subjects in the lower grade, focusing on the training and innovation of the thinking; the higher grade can set the larger subject, and the emphasis should be on the width and depth of the design. The content of the teaching material determines the content of the course teaching. In the light of the principle of openness and practicality and combined with teaching practice, the compilation of teaching materials should reflect the latest information of the art design frontier and the characteristics of systematic and scientific knowledge with a large amount of information.

\section{Cultivate creativity in the course of teaching}

Teaching is a process, a common activity of teachers and students, and a process of cultivating creativity. The core of design teaching is to cultivate students' creativity, namely to cultivate creative thinking and creative ability in the process of teaching. The cultivation of creativity is the core content of modern art design education. The core of modern design education is to mold students' creative consciousness and cultivate students' creativity and to develop students' potential of creative thinking in the course of specific design education. It is necessary to focus on teaching creative methods, creating creative situations, teaching around topics, guiding students into creative roles and arousing students' creative passion. Thus, it can improve students' creative ability and arouse their enthusiasm and initiative in learning. Therefore, the teaching process should be systematic and the teaching methods should be diversified.

\section{Conclusion}

The cultivation of creative talents of the art design major in colleges and universities can meet the needs of the social development of our country. It plays a very important role in relieving the pressure of employment and promoting the development of our society, so we must attach great importance to it. In order to promote the training process of artistic design talents in China, this paper studies the structure of creative quality and the innovative education of artistic design talents in order to do well the education work of cultivating artistic design talents.

\section{References}

[1] Lerner F. Visual - Spatial Art and Design Literacy as a Prelude to Aesthetic Growth[J]. International Journal of Art \& Design Education, 2018, 37.

[2] Hmeshah K, Bronsart R. A Contribution to the Identity Assessment of Ship Structure Plate Parts[J]. Journal of Ship Production \& Design, 2018, 31(1):49-57.

[3] Daphne M V P. Hack the black box: Consumer agency in the sharing economy[J]. Art Design \& Communication in Higher Education, 2018, 17(1):73-87.

[4] Wojan T R, Nichols B. Design, innovation, and rural creative places: Are the arts the cherry on top, or the secret sauce?[J]. Plos One, 2018, 13(2):e0192962.

[5] Bates V. 'Humanizing' healthcare environments: architecture, art and design in modern hospitals[J]. 2018(2250):1-15.

[6] Jiang T. Urban public art and interaction design strategy based on digital technology[J]. Cluster Computing, 2018(4):1-8.

[7] Richards R D. Supporting Young Artists in Making Connections: Moving from Mere Recognition to Perceptive Art Experiences[J]. International Journal of Art \& Design Education, 2018, 37(1):137-148. 